\title{
COVID-19: What Should the General Practitioner Know?
}

Bogna Grygiel-Górniak (D)
Mary-Tiffany Oduah (iD

Department of Rheumatology, Rehabilitation and Internal Diseases, Poznan University of Medical Sciences, Poznan, Poland
This article was published in the following Dove Press journal: Clinical Interventions in Aging

Background: SARS-CoV-2 infection is currently the most significant public health challenge. Its presentation ranges from mild to severe respiratory failure and septic shock. Rapid transmission of the virus is dangerous with a high possibility of life-threatening complications. Lack of treatment standards for SARS-CoV-2 is responsible for the current dilemma in clinical medicine.

Methods: An electronic literature search was done using PubMed to gather information on the pathogenesis, transmission of infection, clinical symptoms, diagnosis, and therapeutic options for COVID-19. Search items included "SARS-CoV-2", "COVID-19" and "coronavirus infection".

Results: In light of the current global crisis caused by SARS-CoV-2, the exchange of information within the scientific community should be quick and extremely transparent. Thus, this review presents the available information necessary for a general practitioner. Such presentation of data should allow the reader quick access to basic and crucial information related to epidemiology, viral transmission, clinical symptoms, diagnostics, treatment, and complications that may occur in the course of COVID-19.

Conclusion: Rapidly increasing amounts of information about the diagnosis and treatment of patients with SARS-CoV-2 allow a better understanding of the etiology and course of the infection. In the current epidemiological situation, readily accessible information helps minimize the time to acquire knowledge and focus on prevention methods, diagnostic and treatment options. Thus, this review highlights key issues related to SARS-CoV-2 infection and contains the most useful data for daily medical practice.

Keywords: coronavirus, COVID-19, signs, diagnosis, treatment

\section{Introduction}

COVID-19 is a newly identified infectious disease of global importance for public health. SARS-CoV-2 belongs to the group of giant single-stranded RNA viruses and is easily transmitted between humans. ${ }^{1}$ Such high infectivity suggests animal origin. ${ }^{2}$ Possible sources of infection include bats, snakes, minks, as well as asymptomatic human carriers who have not yet developed signs of infection. ${ }^{1,3,4}$ Transmission is through respiratory droplets or fomites, but the airborne and orofecal transmission is also likely. ${ }^{5}$ The course of the disease can range from mild (minor respiratory tract infection) to severe pneumonia, acute respiratory distress syndrome (ARDS) associated with multiple organ failure, and death. ${ }^{6}$ The most characteristic symptoms of COVID-19 are fever (in about 90\% of patients), cough, and dyspnoea. ${ }^{5,7-9}$ The digestive tract may be an alternative route of infection, and the virus has been isolated from saliva and feces. ${ }^{10-12}$ Older individuals and those
Correspondence: Bogna Grygiel-Górniak Uniwersytet Medyczny Im.

K. Marcinkowskiego, Zip-Code 6I-70I, Poznań, Poland

Tel +48505 399907

Fax +48618310317

Email bgrygiel@ump.edu.pl
Clinical Interventions in Aging 2021:16 43-56

43 
with several chronic diseases, as well as obese individuals, are more susceptible to infection and acute complications. ${ }^{13,14}$ Treatment depends on the severity of the disease. Symptomatic treatment is used in mild disease presentation (usually antipyretic therapy). Combination therapy including anti-viral drugs, antimalarials, prednisolone, antibiotics, and tocilizumab, is implemented in more severe presentations. ${ }^{15,16}$

\section{Nomenclature}

Initially, severe acute respiratory syndrome coronavirus type 2 (SARS-CoV-2) was called 2019-nCoV. Thus, the name of this virus reflects life-threatening respiratory disorders. Although usually mild, in some high risk groups, it leads to ARDS (acute respiratory distress syndrome), sepsis, and septic shock. ${ }^{17,18}$ The name COVID-19 (coronavirus disease 2019) describes every form of the disease caused by SARS-CoV-2 infection, regardless of severity and complications. The definition of COVID-19 was published by ECDC (European Center for Disease Control and Prevention) and is used when describing the epidemiological, sanitary, and protection recommendations. ${ }^{19}$

\section{Types of Coronaviruses}

Coronaviruses are a large family of encapsulated, singlestranded, zoonotic RNA viruses. These pathogens can affect the respiratory and gastrointestinal tracts, as well as induce hepatic or renal damage, and neurological disorders. ${ }^{1,20}$

The most common are coronaviruses causing respiratory disease, and they belong to the group of alpha and beta-coronaviruses. Four of these $(\mathrm{HCoV} 229 \mathrm{E}$ and $\mathrm{HCoV}-$ NL6 (alpha-coronaviruses) and HCoV-HKU1 and HCoVOC43 (beta-coronaviruses)) are commonly found in humans. ${ }^{1}$ They are most commonly responsible for mild upper respiratory tract infections, bronchitis, or pneumonia. With a rapidly progressive clinical course of SARSCoV-1, SARS-CoV-2, and MERS-CoV (Middle East respiratory syndrome coronavirus), severe pneumonia, acute respiratory distress syndrome, septic shock, and death are observed. ${ }^{6,21-23}$ Molecular studies have shown that SARS-CoV-2 has approximately $79 \%$ sequence identity to SARS-CoV-1, which confirms the high phenotypic similarity of both beta-coronaviruses. Moreover, they bind to the same receptor of the angiotensin II converting enzyme (ACE2); however, there are some differences due to amino acid mutations in some key domains of this receptor. ${ }^{24}$
Short incubation period, droplet transmission, and asymptomatic course influence the high infectivity of SARS-CoV-2, contributing to high rates of transmission worldwide. ${ }^{1,25}$ Besides, SARS-CoV-2 is quickly mutated and recombined, resulting in new forms that can spread from animals to humans. ${ }^{26}$

\section{Epidemiology}

Initially, SARS-CoV-2 was reported only in China, and the first cases involved a small area covering the Chinese seafood market in Wuhan, Hubei Province (December 2019). ${ }^{25}$ However, the virus quickly spread throughout the world. About six weeks later, the World Health Organization (WHO) announced that the infection caused by this pathogen is a threat global public health. ${ }^{27}$ Currently, the SARSCoV-2 pandemic affects all populations and poses a serious challenge to public health organizations. ${ }^{28}$

\section{Transmission of SARS-CoV2 Infection}

As previously mentioned, acute complications such as life-threatening respiratory failure may occur in the course of many coronaviruses, including SARS-CoV-1, SARS-CoV-2, and MERS-CoV. Although MERS-CoV and SARS-CoV-1 have a higher mortality rate due to more severe complications than SARS-CoV-2, the infection caused by SARS-CoV-2 spreads much faster than MERS-CoV and SARS-CoV-1. ${ }^{10,29,30}$ The main mode of transmission for SARS-CoV-2 is via droplets, similar to MERS-CoV and SARS-CoV-1; however, patients with COVID-19 present the highest viral load just before first signs or at the onset of clinical symptoms, which explains the rapid spread of the pathogen and the development of a pandemic. ${ }^{23}$ This fact underlines the importance of rigorous infection control and the strict use of PPE (personal protection equipment). ${ }^{10}$

Rapid transmission of SARS-CoV-2 (much higher than observed in SARS-CoV-1) suggests zoonotic origin. ${ }^{23}$ The most likely natural reservoir of SARS-CoV2 is bats, as well as other wildlife animals such as snakes or minks. ${ }^{1-4}$ The infection is spread primarily by respiratory droplets, as well as transmission between symptomatic and asymptomatic individuals. Moreover, the virus can be transmitted through contact with excretions and secretions of the infected patient. ${ }^{12,31}$

Individuals with confirmed disease, or who have had exposure with infected patients should immediately be 
quarantined. ${ }^{32}$ Asymptomatic carriers present a dangerous route of transmission. A similar viral load is present in both symptomatic and asymptomatic patients, which indicates the potential role of viral transmission by people without any clinical symptoms. ${ }^{33}$ Therefore, any person exposed to an infected patient should be isolated, even in the absence of clinical signs.

The mean incubation period of SARS-CoV-2 (the time from the point of infection to the occurrence of the first symptoms) also influences the quick route of viral transmission; usually lasting 5 days $[5.2$ days $(95 \% \mathrm{CI}=$ 4.1-7.0 days) $(\mathrm{n}=138),{ }^{34} 5.2$ days: range from 2.1 to 11.2 days $(\mathrm{n}=8579)] .^{35}$ The risk of infection diminishes 14 days after contact with an infected patient (this time corresponds with the estimated maximum incubation period). ${ }^{36}$

Data describing the possibility of vertical infection are controversial. Zhang et al reported observations of 4 newborns which suggested the possibility of vertical transmission from mother to child. However, in infected newborns, there were no serious complications or need for mechanical ventilation or treatment in the ICU. Thus, newborns are susceptible to SARS-CoV-2, but their symptoms are milder compared to adults. ${ }^{37}$ Conversely, research by Liu et al describing 19 pregnant infected women did not confirm a mother-child transmission during childbirth. Besides, no perinatal complications of pregnant women during the third trimester of pregnancy or newborns were found. All newborns were born healthy and had no SARSCoV-2 infection. ${ }^{38}$ Therefore, the concept of vertical transfer of SARS-CoV-2 deserves further investigation. ${ }^{37}$

\section{Disease Severity-Dependent Course of Infection}

Patients with SARS-CoV-2 present a broad spectrum of symptoms, from mild/moderate infection to severe and rapidly progressive and life-threatening disease. ${ }^{17,18}$ Epidemiological data from the Chinese population show that about $81 \%$ of patients have mild symptoms (including mild pneumonia), and $1.2 \%$ of patients are asymptomatic. $^{39}$

\section{An Age-Dependent Course of Infection}

The most vulnerable to infection is the senior group. The risk of an acute course of the disease increases with age, and patients over 60 years present the most severe complications. ${ }^{15,34}$ They are more susceptible to the infection than children, more frequently suffer from dyspnea, and rapidly progressive disease (ARDS, septic shock). As a result, the elderly are the most frequently hospitalized group of patients in intensive care units (ICU). ${ }^{5,15,34}$ Studies of the Chinese population showed that patients with severe COVID-19 complications, were on average, seven years older than patients with mild symptoms, and more frequently present with higher comorbidities. ${ }^{5}$ Physiological changes characteristic of normal aging, declining physical performance, malnutrition, cognitive decline, and depressive state explain this phenomenon. ${ }^{40}$ It is worth noting that polypragmasia, due to overprescription of medication in the setting of poorly coordinated care, is more often observed in this group of patients. These factors increase the risk of drug side effects with a negative influence on overall health. ${ }^{13}$ It is also worth emphasizing that the course of infection can be atypical in the elderly and patients with immunodeficiency, with a high risk of serious complications even in mild disease. ${ }^{13,15,34}$

In children, the disease is usually mild or asymptomatic, ${ }^{34}$ especially in neonates. ${ }^{37,38}$ In this group of patients coronaviruses cause fewer clinical symptoms and are rarely fatal. ${ }^{19}$ In infants, the course of the disease is usually mild or asymptomatic. ${ }^{37,38,41}$ In older children, COVID-19 may co-exist with other viral or bacterial infections and should be treated alongside SARS-CoV-2. ${ }^{42,43}$ Most children have documented home contacts, and the symptoms often appear quicker than in adult household members. Children, unlike adults, are less frequently hospitalized due to severe complications of SARS-CoV-2. ${ }^{6}$ Thus, current data indicate that in the pediatric population, SARS-CoV-2 infection is rarely symptomatic and is less severe than in adults. ${ }^{19}$

\section{Comorbidity-Dependent Course of SARS-CoV-2 Infection}

Increased morbidity of COVID19 is observed in patients with chronic diseases such as diabetes, hypertension, and COPD. ${ }^{7,13}$ Zhou et al have shown that the co-occurrence of diabetes and hypertension and the deterioration of functional performance in COVID-19 increases the risk of death in older patients (ZhouF). The risk of a severe course of infection is also observed in the case of obesity. Andersen et al, in their review, underline diminished immune function in individuals with obesity, and thus, SARS-CoV-2 infection raises 
essential questions about the possibility of higher viral pathogenicity in this population. ${ }^{14}$ Recently, vitamin $\mathrm{D}$ is widely discussed in the context of its positive influence on immune function. The meta-analysis of Martineau et al has shown that vitamin D supplementation protects against acute respiratory tract infection overall. Patients who were vitamin $\mathrm{D}$ deficient and those not receiving bolus doses experienced the most benefit during adequate supplementation of this vitamin. $^{44}$

\section{Clinical Symptoms}

The clinical signs may vary between different populations, due to the influence of environmental and genetic factors. The disease course may be mild or moderate. The virus typically affects the respiratory tract, and patients complain of fever, cough (most often dry), sore throat, fatigue, and malaise $e^{5,7-9}$ (Table 1). Dyspnea increases with the progression of the disease. Headaches and myalgia may also occur. If pneumonia develops, it can be mild and responsive to treatment, or severe requiring oxygen therapy or mechanical ventilation. 5,8
The disease infrequently begins with extra-pulmonary (eg, gastrointestinal) symptoms. Recent studies have confirmed the tropism of SARS-CoV-2 to the gastrointestinal tract (detectable on intestinal biopsy and fecal matter). ${ }^{45}$ Angiotensin II receptors (ACE-2) enable the entry of SARS-CoV-2 into lung tissue and enterocytes in small intestines; this explains symptoms such as diarrhea, vomiting, nausea, and abdominal pain. ${ }^{46,47}$ Viral genetic material has been found in the stool, and elimination time from the gastrointestinal tract is more prolonged compared to the respiratory tract. ${ }^{12,31}$ SARS CoV-2 infection can also lead to direct damage to intrahepatic bile ducts due to the high expression of ACE2 receptors on 59.7\% of cholangiocytes. For comparison, these receptors are present only on $2.6 \%$ hepatocytes. ${ }^{48}$ SARS-CoV-2 has also been confirmed in the saliva and thus can be a potential route of infection. ${ }^{45}$ Therefore gastroenterological symptoms may co-exist with upper respiratory tract symptoms and may account for further transmission of the SARS-CoV-2 through the digestive tract. However, side effects of medications used for anti-viral treatment

Table I Clinical Symptoms and the Course of SARS-CoV-2 Infection

\begin{tabular}{|c|c|c|c|c|}
\hline $\begin{array}{l}\text { Infected } \\
\text { patients [\%] }\end{array}$ & $60-90 \%$ & $20-59 \%$ & $5-19 \%$ & $<5 \%$ \\
\hline symptoms & $\begin{array}{l}\text { - fever } \\
\text { - cough } \\
\text { - dyspnoea } \\
\text { - lymphocytopenia }\end{array}$ & $\begin{array}{l}\text { - muscle pain or tiredness } \\
\text { - presence of sputum } \\
\text { - fatigue } \\
\text { - smell and taste disorders (loss of smell } \\
\text { is often present before fever and can be } \\
\text { the dominant symptom of infection) }\end{array}$ & $\begin{array}{l}\text { - headache } \\
\text { - } \text { hemoptysis } \\
\text { - } \text { sore throat } \\
\text { - diarrhea } \\
\text { - } \text { shortness of breath } \\
\text { - chills } \\
\text { - nausea or vomiting }\end{array}$ & $\begin{array}{l}\text { - swelling of the } \\
\text { nasal mucosa } \\
\text { - enlargement of } \\
\text { palatine tonsils } \\
\text { - conjunctival } \\
\text { hyperemia } \\
\text { - lymph nodes } \\
\text { - enlarged } \\
\text { - rash }\end{array}$ \\
\hline $\begin{array}{l}\text { COVID-19 } \\
\text { complications }\end{array}$ & \multicolumn{2}{|c|}{ most often pneumonia - present in $>90 \%$ of patients (usually a ground-glass shadow on chest CT) } & \multicolumn{2}{|c|}{$\begin{array}{l}\text { - } \text { ARDS } \\
\text { - } \text { rarely: } \\
\text { - } \text { septic shock } \\
\text { - carde kidney failure } \\
\text { - rhabdomyolysis } \\
\text { - DIC (disseminated intravascular } \\
\text { coagulation) }\end{array}$} \\
\hline $\begin{array}{l}\text { The course of } \\
\text { SARS-CoV-2 } \\
\text { infection }\end{array}$ & $\begin{array}{l}\text { mild } \\
\text { - most patients ( } 81 \%) \\
\text { out clinical complications } \\
\text { - hospitalization is not required (the exception are the } \\
\text { elderly who should be carefully monitored because of } \\
\text { the high risk of sudden clinical disease exacerbation) }\end{array}$ & $\begin{array}{l}\text { severe } \\
\text { - } 14 \% \text { of patients } \\
\text { - patients require hospitalization and } \\
\text { oxygen therapy }\end{array}$ & $\begin{array}{l}\text { critically ill } \\
\text { - } 5 \% \text { of patients } \\
\text { - ICU treatment is req } \\
\text { - critically ill patient } \\
\text { severe pneumonia } \\
\text { - mechanical ventilatior }\end{array}$ & $\begin{array}{l}\text { uired } \\
\text { s frequently with } \\
\text { usually is needed }\end{array}$ \\
\hline
\end{tabular}

Note: Data based on research from Guan et al, ${ }^{5}$ Zhao et al, ${ }^{7}$ and Chakraborty et al ${ }^{8}$ 
should always be excluded. ${ }^{49}$ Thus, the oral route may be an alternative way of transmission, especially with exposure to infected wild animals or asymptomatic carriers. $^{4,23}$

SARS-CoV-2 infection may cause loss of smell, which is observed in $20-60 \%$ of patients with the confirmed disease (data according to the European Rhinologic Society). Moreover, this often occurs before fever and can be the predominant sign of infection. ${ }^{50}$ A multicentre study of the 417 infected patients with mild to moderate COVID-19 showed that almost $86 \%$ of patients present with olfactory dysfunction, and $88.0 \%$ reported dysgeusia. These symptoms were more common in women. Sensory and olfactory disorders were present before other symptoms in $11.8 \%$ of patients. ${ }^{51}$

\section{Clinical Interview}

History of presenting symptoms and travel history must be elicited in order to estimate the risk of the SARS-CoV-2 infection. It is essential to obtain information about exposures in people with international travel.

\section{Clinical Examination}

The symptoms are lightly expressed in mild disease. Patients with severe symptoms often report shortness of breath. Auscultatory small-bubble rales are mainly heard at the base of both lungs, accompanied by increased vocal tremors over the inflammatory lung tissue area and diminished resonance. Pleural effusion is rare, but if it is present, diminished respiratory sounds, the abolition of vocal tremor, and diminished percussion notes are observed. ${ }^{52}$

\section{Imaging Examination}

Lesions present on chest X-ray or CT depend on disease severity, varying from small infiltration at early stages (normal or slight and bilateral patchy shading, slight interstitial infiltrations, or changes more strongly expressed in the peripheral part of the lung), ${ }^{8}$ to massive interstitial pneumonia. ${ }^{5}$ The progression of pulmonary infiltrates is observed in almost $50 \%$ of the patients, and it progresses rapidly (3.5 days on average). The resolution of inflammatory infiltration is found in approximately $25 \%$ of cases, while $25 \%$ of patients do not show significant changes on imaging studies. ${ }^{9}$

Pulmonary infiltration is the most common sign on chest CT. It is usually described as bilateral spotty shadings or ground-glass changes. ${ }^{5,9}$ They are bilaterally distributed, more pronounced in the periphery, and are most often noted in more than two lobes. ${ }^{9,53}$ However, they are similar to that of other coronaviruses infection, such as SARS-CoV- ${ }^{21}$ and MERS-CoV. ${ }^{22} \mathrm{CT}$ imaging is essential in recognizing and monitoring pulmonary changes in COVID-19. Chest CT may be more sensitive (98\% sensitivity) in detecting SARS-CoV-2 infection than RT-PCR (71\% sensitivity). ${ }^{54}$

In the early stage of the chest X-ray may be present slight and patchy shading more strongly expressed in the peripheral part of the lung. In advanced disease, numerous infiltration and consolidative modifications on both sides are observed. CT usually shows spotty bilateral shadowing, mainly in the peripheral part of the lung; however, milky-glass shading or interstitial changes $(>80 \%$ of patients have more than two lobes involved) are also detected. $5,8,9$

\section{Molecular Diagnostics SARS-CoV-2 Infection Biological Material}

The complete genome sequence of SARS-CoV-2 is available; thus, genetic material may be isolated from lower and upper respiratory tract samples. Specimens may be obtained from the saliva, feces or blood (in sepsis). ${ }^{11,31,45,49}$ Thus, a variety of specimens (such as nasopharyngeal swabs, sputum, tracheal extracts, lung tissue, blood, and feces) can be taken for viral RNA detection.

The most common method for the identification of SARS-CoV-2 is swabbing nasopharyngeal or oral cavity. ${ }^{55}$ PCR is most sensitive if the material is obtained from the lower respiratory tract (usually aspirate from the trachea or bronchoalveolar lavage (BAL)). ${ }^{29,56}$ The possibility of detecting viral RNA by RT-PCR in a single nasopharyngeal swab is not high; therefore, tests should be repeated. $^{11,57}$ The accuracy of the PCR assay increases with repeated sampling giving rise to a lower number of false-negative results. ${ }^{18}$

Samples should not be taken from the nostrils or tonsils. Swab sticks should be sterile and made of synthetic, non-cotton material. Sputum (if occurring in the course of the disease) may be used for virus detection, but should not be induced due to the increased risk of infection by aerosol. Procedures for obtaining nasopharyngeal swabs, recommended for detection of SARS-CoV-2, are considered as aerosol-generating procedures. For this reason, 
they should be performed in specific facilities with adequate protection of medical staff. ${ }^{58,59}$

Analysis of subsequent saliva samples in recovering persons showed a decreasing viral load in the collected material. ${ }^{45}$ SARS-CoV-2 genetic material has been found in the stool of patients with gastrointestinal symptoms. ${ }^{12,31}$ Although the virus can be detected in saliva or feces, this is not a standard method of virus identification since it is not observed in all patients infected with SARS-CoV-2 (such determination is more often performed in scientific research). ${ }^{12,31}$

\section{Molecular Diagnostics}

Quantitative determination of coronavirus material by real-time RT-PCR (reverse transcriptase-polymerase chain reaction) and sequencing of the genetic material of the virus is the gold standard in diagnosing COVID$19 .^{55}$ Real-time RT-PCR is characterized by high specificity and sensitivity and is useful for confirming active infection (the period of virus replication). ${ }^{29,56}$ Positive of RT-PCR results indicate the presence of a virus and is considered as evidence of a current infection. A negative result may reflect the lack of infection, if the material for the tests was collected correctly and promptly, at the time of the highest viremia. However, the result should be repeated, and if negative results are repeated samples confirms the lack of viremia. However false-negative result might also present and can result from sampling before or after the highest viremia, various sites of collection (PCR is less sensitive for a nasal swab than for a nasopharynx swab), inappropriate material collection for swab tests, which leads to the breakdown of genetic material, improper transport destroying the viral nucleic acids, eg, inadequate temperature, sample contamination, and incorrect performance of the RT-PCR assay. ${ }^{55,56}$

With a positive RT-PCR test and minor symptoms, quarantine, as well as symptomatic treatment, is indicated. ${ }^{61}$ The RT-PCR analysis should be repeated if symptoms worsen or new symptoms characteristic for SARS-CoV-2 infection appear. ${ }^{45}$ Viremia increases along with worsening of clinical state, increasing severity of clinical symptoms (rising fever, dyspnea, sputum production, and weakness), and the progression of inflammatory changes in chest imaging studies. ${ }^{60}$

\section{Biochemical Study}

During the course of the SARS-CoV-2 infection, several changes are observed in serum biochemistry. Leukopenia (defined as $\mathrm{WBC}<4000 / \mu \mathrm{L}$ ) is found in about one-third of patients. Less often, leukocytosis or normal white blood cell count is observed. ${ }^{62}$ Leukopenia is more notable in patients with severe COVID-19. Quite characteristic for SARS-CoV-2 infection is lymphocytopenia (defined as lymphocyte count $<1500 / \mu \mathrm{L}$ ), which is usually observed in more than $80 \%$ of patients. ${ }^{5,62}$ Lymphocytopenia also correlates with disease severity. Approximately $20 \%$ of patients manifest liver disorders (with elevated ALT and AST), and increased inflammatory markers. ${ }^{5}$

\section{Differential Diagnosis of Pulmonary Changes in COVID-19}

It is crucial to know that a positive bacterial or viral test for pathogens other than COVID-19 does not exclude the presence of SARS-CoV-2. This may be explained by a low SARS-CoV-2 viral load. Studies indicate that patients with SARS-CoV-1, MERS, or SARS-CoV-2 virus may be coinfected with other respiratory pathogens. ${ }^{43}$ Therefore, identification of other viral (influenza A and B, parainfluenza, adenoviruses and rhinoviruses, RSV (respiratory syncytial virus), SARS-CoV-1, hMPV - human metapneumovirus, endemic human coronavirus, eg, HKU1, OC43, NL63 and 229E, arboviruses (dengue/chikungunya viruses) in endemic areas), bacterial (Mycoplasma, Chlamydia, Legionella), or parasitic pathogens does not exclude COVID-19 infection. ${ }^{63}$

\section{Treatment of SARS-CoV-2 Infection}

\section{General Recommendations}

COVID-19 should be suspected in any patient with symptoms of severe respiratory infection such as fever, cough, or shortness of breath. The possibility of infection increases if the patient had contact with an infected person within 14 days of symptom onset or contact with a person who has returned from the area of local COVID-19 transmission. ${ }^{36}$ To date, clinical data of the treatment of SARS-CoV-1 acute respiratory distress syndrome has shown that early diagnosis of suspected cases and prompt implementation of preventive and therapeutic measures are crucial for preventing and ceasing epidemics. ${ }^{67}$ 


\section{Recommendations for Medical Personnel}

Caring for an infected patient requires proper security of medical staff by using personal protective equipment appropriate to the performed procedures (WHOct). Depending on the clinical situation, surgical masks, filter masks (eg, N95 masks), or providing a higher level of protection can be used. Highly filtration masks such as N95 masks and protective clothing (glasses and aprons) should be used in public healthcare institutions, particularly in places where healthcare professionals have direct contact with infected patients (WHOct) (National). In these situations, eye protection glasses, gloves, and long-sleeved aprons (preferably disposable) are also necessary. It is important not to touch the eyes, nose, and mouth after putting on gloves and avoid contaminated surfaces, such as door handles or light switches. Contact with an infected person should be associated with frequent hand hygiene, and each time disinfection of reusable equipment (National).

Regardless of the course of the disease, isolation is necessary for every patient to stop spreading the virus (at home, in hospital, in nursing homes, orphanages, or other facilities). Such patients should be given clear instructions regarding hygiene rules and a proper home or institutional conditions of isolation. Each of them should be informed to which hospital they should go in case of health deterioration $(\mathrm{ECDC})$.

\section{Treatment Strategies of COVID-19}

Treatment of SARS-CoV-2 infection depends on the clinical severity, age, and risk factors for possible disease complications. ${ }^{61}$ Symptomatic treatment (antipyretic) and home isolation (no hospitalization is required) is indicated in mild infection. Combined therapy, including pharmacological and supportive treatment (eg, oxygen therapy or mechanical ventilation), should be implemented in severe cases. ${ }^{68,69}$

\section{Currently Tested Therapies in COVID-19 RCTs}

Recent data report conflicting information about the use of anti-viral (eg, lopinavir/ritonavir), antimalarial (chloroquine or hydroxychloroquine), and anti-inflammatory drugs. Some studies report positive effects of antibiotics such as azithromycin. Remdesivir and tocilizumab should be considered in patients with exacerbation of the disease. ${ }^{15}$ Due to insufficient literature on the efficacy and safety of available drugs, the decision to use them must be made carefully by the physician. ${ }^{16}$
Current evidence indicates that we are still at a loss for targeted therapy against COVID-19 infection in clinical practice. Several drugs have been trialed in vitro and others are still being investigated in clinical trials. There is a lack of conclusive data for available therapies with the exception of antivirals and glucocorticoids. Inadequate study power, study duration, and lack of control groups are important key factors decreasing the quality evidence of some available studies. These are summarized in Table 2.

\section{Severe Course of SARS-CoV-2 Infection}

Alarming symptoms in the course of SARS-CoV-2 infection include obstruction of the respiratory tract or lack of breath, severe respiratory distress, central cyanosis, shock, convulsions, and coma. ${ }^{13}$ In addition to pharmacological treatment, respiratory protection and complementary oxygen therapy are needed to achieve $\mathrm{SpO} 2$ saturation $>94 \%$. The right fluid supply is also crucial for proper patient hydration. However, it is of notice that aggressive fluid administration increases the risk of saturation worsening. ${ }^{13,65,66}$

Poor prognosis risk factors include older age, high SOFA score (Sepsis-related Organ Failure Assessment), ${ }^{64}$ and D-dimer value above $1 \mu \mathrm{g} / \mathrm{mL}$. These factors can enable the identification of patients with poor prognosis at admission to the hospital. In such patients, treatment should be immediately implemented, and strict monitoring should be considered. ${ }^{13}$ During treatment, it is crucial to achieving adequate saturation $(\mathrm{SpO} 2>94 \%)$ and proper hydration of patients. ${ }^{87}$ Close monitoring of patients should include vital signs examination, risk assessment of rapidly progressing respiratory failure and sepsis, as well as treatment of concomitant chronic diseases or their temporary suspension depending on the patient clinical condition and drug interactions. ${ }^{88}$

\section{Challenges to General Practitioners in the COVID-19 Outbreak}

The data of other epidemics (eg, an influenza outbreak in Ontario) have showed the critical importance of engaging early and effectively with primary care. ${ }^{93}$ General practitioners provide medical surveillance in the community; however, they are at higher risk of SARS-CoV-2 infection (Figure 1). They have had contact with many patients daily, mainly during the first days of the disease, when the information about COVID-19 spreading and safety procedures were scant. They had close contact with 
Table 2 Drugs Currently Used or Under Investigation for COVID-19

\begin{tabular}{|c|c|c|c|}
\hline Drug & Drug Class: Mechanism of Action & Study: Study Findings & Indication/Standard Dose \\
\hline \multirow[t]{2}{*}{$\begin{array}{l}\text { Remdesivir (GS- } \\
\text { 5734) }\end{array}$} & $\begin{array}{l}\text { Antiviral: prodrug of an adenosine } \\
\text { C-nucleoside leading to decreased viral RNA } \\
\text { production }^{70}\end{array}$ & $\begin{array}{l}\text { Wang et al 2020. A double-blind study in } 236 \\
\text { patients. Intravenous Remdesivir vs placebo: } \\
\text { dose tolerated; no statistically significant clinical } \\
\text { benefits, however, numerical reduction in time } \\
\text { to clinical improvement were observed }\end{array}$ & $\begin{array}{l}200 \mathrm{mg} \text { on day I followed by } 100 \mathrm{mg} \text { on days } \\
2-10 \text { in single daily infusions }\end{array}$ \\
\hline & & $\begin{array}{l}\text { Grein et al 2020. A preliminary prospective } \\
\text { compassionate-use cohort study of } 61 \text { patients: } \\
\text { high incidence of adverse effects; improvement } \\
\text { in oxygen-support requirement was observed in } \\
68 \% \text { of patients, overall mortality of } 13 \% \text { over } \\
\text { a median follow-up of } 18 \text { days }^{72}\end{array}$ & $\begin{array}{l}\text { Patients with confirmed SARS-CoV- } 2 \\
\text { infection (by RT-PCR) and oxygen saturation } \\
\text { of } \leq 94 \% \text { on ambient air or on oxygen } \\
\text { support. } 200 \mathrm{mg} \text { intravenously on day } \mathrm{l} \text {, } \\
\text { followed by } 100 \mathrm{mg} \text { daily for the remaining } 9 \\
\text { days }\end{array}$ \\
\hline \multirow[t]{5}{*}{$\begin{array}{l}\text { Antimalarial } \\
\text { drugs: } C Q \text { and } \\
\text { HCQ }\end{array}$} & $\begin{array}{l}\text { AMD: accumulation of } \mathrm{CQ} \text { in lysosomes } \\
\text { alters the } \mathrm{pH} \text { thus activating proteases in } \\
\text { lysosomes and thus affecting the degradation } \\
\text { of proteins and glycosaminoglycan }\end{array}$ & $\begin{array}{l}\text { Liu et al 2020. In Vitro study, Vero E6 cell line: } \\
\text { HCQ efficiently inhibits SARS-CoV-2 infection } \\
\text { in vitro }^{73}\end{array}$ & $\begin{array}{l}\text { Vero E6 cells were treated with CQ or HCQ } \\
(50 \mu \mathrm{M}) \text { for I hour }\end{array}$ \\
\hline & & $\begin{array}{l}\text { inhibits SARS-COV-2 at low-micromolar } \\
\text { concentrations }^{74}\end{array}$ & $\begin{array}{l}\text { Polish recommendations: } \\
\text { Chloroquine, orally, } 250 \mathrm{mg} \text { p.o.(in specific } \\
\text { cases } 500 \mathrm{mg} \text { ) every } 12 \text { hours, } 7-10 \text { days (no } \\
\text { more than } 10 \text { days) }\end{array}$ \\
\hline & $\begin{array}{l}\mathrm{CQ} \text { can inhibit the entry of SARS-CoV-2 and } \\
\text { prevent virus-cell fusion by interfering with } \\
\text { glycosylation of ACE2 receptor and its } \\
\text { binding with spike protein }\end{array}$ & $\begin{array}{l}\text { Gautret et al, } 2020 \text {. RCT with } 36 \text { patients treated } \\
\text { with } \mathrm{HCQ}( \pm \text { Azithromycin): reduction in viral } \\
\text { load by day } 6 \text { post-inclusion; synergy observed } \\
\text { with the combination of hydroxychloroquine and } \\
\text { azithromycin }{ }^{75} \text { Wang et al, } 2020 \text {. In vitro study: } \\
\text { potent inhibition of coronavirus with } \mathrm{CQ}^{74}\end{array}$ & $\begin{array}{l}600 \mathrm{mg} \text { of hydroxychloroquine daily } \\
+ \text { Azithromycin } 500 \mathrm{mg} \text { on dayl then } 250 \mathrm{mg} \\
\text { per day, subsequent } 4 \text { days }\end{array}$ \\
\hline & $\begin{array}{l}\text { HCQ possesses an anti-inflammatory effect } \\
\text { on Th 17-related cytokines (IL-6, IL-17, and } \\
\text { IL-22) }\end{array}$ & $\begin{array}{l}\text { HCQ causes quick viral clearance in combined } \\
\text { therapy with azithromycin }{ }^{75}\end{array}$ & $\begin{array}{l}\text { The oral loading dose of HCQ } 400 \mathrm{mg} \text { bid on the } \\
\text { first day, and the maintenance dose of } 200 \mathrm{mg} \text { bid } \\
\text { continue to be treated for four days }{ }^{76} \text {. }\end{array}$ \\
\hline & & $\begin{array}{l}\text { Overall, it appears that good results have been } \\
\text { seen in vitro, however, robust clinical data to } \\
\text { support the use of } \mathrm{HCQ} \text { in clinical practice is } \\
\text { lacking. A systematic review reveals that there } \\
\text { is still a lack of clinical studies demonstrating } \\
\text { the efficacy of } C Q / H C Q \text { in vivo }{ }^{89}\end{array}$ & \\
\hline \multirow[t]{2}{*}{$\begin{array}{l}\text { Lopinavir/ } \\
\text { Ritonavir (LPV/r) }\end{array}$} & \multirow[t]{2}{*}{ Protease inhibitor } & $\begin{array}{l}\text { Cao et al, 2020. RCT of } 199 \text { patients: no } \\
\text { benefit was observed with LPV/r treatment } \\
\text { beyond standard care }\end{array}$ & $\begin{array}{l}400 \mathrm{mg} / 100 \mathrm{mg} \text {, orally twice daily plus } \\
\text { standard of care, or standard of care alone }\end{array}$ \\
\hline & & $\begin{array}{l}\text { Ye et al, 2020. A retrospective cohort study of } \\
47 \text { patients treated with } L P V / r \text { plus adjuvant } \\
\text { drugs: shorter time to temperature } \\
\text { normalization and negative viral } R_{N A}{ }^{78}\end{array}$ & $\begin{array}{l}5 \mathrm{~mL} / \text { dose }(400 / 100 \mathrm{mg}) \text { for adults, twice } \\
\text { a day or } 10 \mathrm{~mL} / \text { dose }(800 / 200 \mathrm{mg}) \text { once a day } \\
\text { with food plus adjuvant drugs }\end{array}$ \\
\hline
\end{tabular}

(Continued) 
Table 2 (Continued).

\begin{tabular}{|c|c|c|c|}
\hline Drug & Drug Class: Mechanism of Action & Study: Study Findings & Indication/Standard Dose \\
\hline \multirow[t]{2}{*}{$\begin{array}{l}\text { Biologic anti- } \\
\text { cytokine drugs }\end{array}$} & \multirow[t]{2}{*}{$\begin{array}{l}\text { Immunomodulator: Humanized monoclonal } \\
\text { antibody against IL-6 }\end{array}$} & $\begin{array}{l}\text { Tocilizumab } \\
\text { Xiaoling et al } 2020 \\
\text { A retrospective study of } 20 \text { patients: } \\
\text { radiographic evidence of pulmonary lesion } \\
\text { resorption in } 90 \% \text {, temperature normalization } \\
\text { after day I of treatment }\end{array}$ & $\begin{array}{l}400 \mathrm{mg} \text { intravenous drip Tocilizumab in } \\
\text { addition to standard care plus lopinavir, } \\
\text { methylprednisolone. No control arm. }\end{array}$ \\
\hline & & $\begin{array}{l}\text { Siltuximab } \\
\text { Gritti et al, } 2020 \text {. Normalization of serum } \\
\text { CRP level by day } 5,33 \% \text { showed a decreased } \\
\text { need for } \mathrm{O} 2 \text { support }^{80}\end{array}$ & $\begin{array}{l}\text { Intravenously at a dose of } 1 \mathrm{I} \mathrm{mg} / \mathrm{kg} / \text { day over } \\
\text { I hour; dose ranging from } 700 \text { to } 1200 \mathrm{mg} \\
\text { (median dose }=900 \mathrm{mg} \text { ) } \\
\text { A second dose could be administered per } \\
\text { compassionate-use program (Five patients } \\
\text { received a second dose of siltuximab) }\end{array}$ \\
\hline Ivermectin & $\begin{array}{l}\text { Anti-helminthic drug with Anti-viral } \\
\text { property: Inhibition of IMP } \alpha / \beta I \text {-mediated } \\
\text { nuclear import of viral proteins } \rightarrow \text { inhibition } \\
\text { of viral RNA replication }\end{array}$ & $\begin{array}{l}\text { Caly et al, } 2020 \text {. } \\
\text { In vitro study in SARS-CoV-2 infected Vero/ } \\
\text { hSLAM cell line. } \\
\text { Post-infection samples were taken for viral } \\
\text { load quantitation (real-time PCR) of cell- } \\
\text { associated virus or supernatant: Injected at } 2 \mathrm{~h} \\
\text { post-infection, ivermectin affected } ~ 5000 \text {-fold } \\
\text { reduction in viral RNA at } 48 \mathrm{~h}^{81}\end{array}$ & Serial dilutions of Ivermectin. IC50 $\sim 2 \mu \mathrm{M}$ \\
\hline \multirow[t]{2}{*}{$\begin{array}{l}\text { Convalescent } \\
\text { Plasma (CP) }\end{array}$} & $\begin{array}{l}\text { Binding of the transfused antibodies to the } \\
\text { pathogen, resulting in cellular cytotoxicity, } \\
\text { phagocytosis, or direct neutralization of the } \\
\text { pathogen }\end{array}$ & $\begin{array}{l}\text { Shen et al, } 2020 . \\
\text { Case series report of } 5 \text { patients: decrease in } \\
\text { SOFA score, increase in PAO2/FiO2, ARDS } \\
\text { resolution, and negative viral load by day } 12 \text {. } \\
\text { Increase in neutralizing antibodies by day } 7^{82}\end{array}$ & 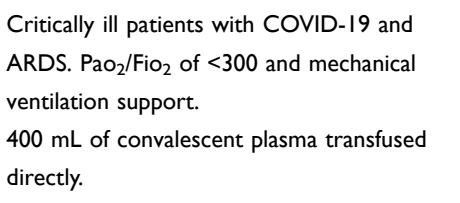 \\
\hline & & $\begin{array}{l}\text { Duan et al } 2020 \\
\text { A pilot cohort study to evaluate the safety of } \\
\mathrm{CP} \text { in } 10 \text { patients: well tolerated with no } \\
\text { adverse effects. Improved oxygen saturation, } \\
\text { lymphocyte count, CRP, clinical status and } \\
\text { resorption of lung lesions by day } 7^{83}\end{array}$ & $\begin{array}{l}200 \mathrm{~mL} \text { of convalescent plasma transfused } \\
\text { directly }\end{array}$ \\
\hline \multirow[t]{2}{*}{ Corticosteroids } & Anti-inflammatory & $\begin{array}{l}\text { Villar et al, } 2020 \text {. Multicenter placebo- } \\
\text { controlled RCT of Dexamethasone in } 277 \\
\text { patients: no difference in the incidence of } \\
\text { adverse effects (hyperglycemia, new infections, } \\
\text { barotrauma); a significant decrease in } 60 \text {-day } \\
\text { mortality and increased number of ventilator- } \\
\text { free days in Dexamethasone arm }{ }^{84}\end{array}$ & $\begin{array}{l}\text { An intravenous dose of } 20 \mathrm{mg} \text { once daily (day } \\
\text { I to } 5 \text { ), then reduced to } 10 \mathrm{mg} \text { once daily } \\
\text { (day } 6 \text { to } 10 \text { ) }\end{array}$ \\
\hline & & $\begin{array}{l}\text { The RECOVERY trial was a randomized } \\
\text { control trial in } 2108 \text { patients with COVID. It } \\
\text { revealed a decrease in } 28 \text {-day mortality in } \\
\text { patients receiving dexamethasone. It } \\
\text { decreased incidence of mortality by a third in } \\
\text { patients on mechanical ventilation compared } \\
\text { to those without }{ }^{90} \\
\text { Interestingly, patients who receive delayed } \\
\text { mechanical ventilation and are tolerating } \\
\text { modest to moderate hypoxia have better } \\
\text { outcomes than their counterparts. High PEEP } \\
\text { ventilation has been linked with higher } \\
\text { mortality in COVID-induced lung injury. }{ }^{91,92}\end{array}$ & \\
\hline
\end{tabular}

(Continued) 
Table 2 (Continued).

\begin{tabular}{|c|c|c|c|}
\hline Drug & Drug Class: Mechanism of Action & Study: Study Findings & Indication/Standard Dose \\
\hline Heparin & $\begin{array}{l}\text { Anti-inflammatory action } \\
\text { May inhibit viral attachment via } \\
\text { conformational changes to the SARS-CoV-2 } \\
\text { surface receptor (Spike) SI }\end{array}$ & $\begin{array}{l}\text { Tang et al, 2020. A retrospective cohort study } \\
\text { of } 449 \text { patients randomized to heparin or } \\
\text { LMWH vs placebo: anticoagulation conferred } \\
\text { survival benefit in patients meeting SIC criteria } \\
\text { or with markedly elevated D-dimer (at least } \\
6 \times \text { ULN). Overall no difference in } 28 \text {-day } \\
\text { mortality in heparin users and non-users }{ }^{85}\end{array}$ & $\begin{array}{l}\text { A } 7 \text {-day course of } 40-60 \mathrm{mg} \text { enoxaparin/day } \\
\text { OR } \\
10,000-15,000 \mathrm{U} \text { of UFH/day }\end{array}$ \\
\hline \multirow[t]{2}{*}{$\begin{array}{l}\text { Nutritional } \\
\text { Supplements }\end{array}$} & $\begin{array}{l}\text { Zinc inhibits SARS-CoV and retrovirus RNA } \\
\text { polymerase activity in vitro, and zinc } \\
\text { ionophores block the replication of these } \\
\text { viruses in cell culture } \\
\text { Zinc enhances chloroquine intracellular } \\
\text { uptake }\end{array}$ & No concluded trials & $\begin{array}{l}1200 \mathrm{mg} / \text { day intravenous infusion plus } \\
\text { standard of care }\end{array}$ \\
\hline & $\begin{array}{l}\text { Lipoic acid induces } \mathrm{HO}-\mathrm{I} \text { potentially } \\
\text { boosting interferon I response }\end{array}$ & $\begin{array}{l}\text { Zhong et al } 17 \text { patients in Placebo-controlled } \\
\text { RCT: lower SOFA score increase and lower } \\
\text { 30-day all-cause mortality compared to } \\
\text { placebo, albeit statistically insignificant } \\
\text { McCarty and DiNicolantonio } 2020^{87}\end{array}$ & $1200-1800 \mathrm{mg}$ \\
\hline
\end{tabular}

Abbreviations: $\mathrm{CQ}$, chloroquine; $\mathrm{HCQ}$, hydroxychloroquine; RT-PCR, reverse transcriptase-polymerase chain reaction; IMP $\alpha / \beta I$, importin alpha/beta; CRP-C, reactive protein; RCT, randomized control trial; HO-I, heme oxygenase I; LMWH, low molecular weight heparin; SIC score, sepsis-induced coagulopathy score; ULN, upper limit of normal; UFH, unfractionated heparin.

infected patients during medical examinations (shorter than two meters).$^{94}$ The study of Ing et al ${ }^{95}$ describes the death of 278 physicians who died with COVID-19 infection (the average age of the physicians was 63.7 years with a median age of 66 years). About $42 \%$ of them were general practitioners and emergency room doctors. ${ }^{95}$ Similar statistics were presented in the population of Italian physicians, which have shown that general practitioners are the most heavily affected group, and they represent $44.1 \%$ of the total COVID-19 related death cases that occurred among physicians. ${ }^{94}$ Unfortunately, lack of personal protective equipment was cited as a common cause of death. The authors suggested that older physicians should avoid front-line work with COVID-19 patients (Ing). Because GP is at high risk of getting infected during in-person visits, thus their activity should be reduced to a minimum level. Nevertheless, the role of GP is crucial in the process of diagnosing the clinical symptoms of COVID-19 via various tools of telemedicine and delivering information about continuous care for patients who are chronically ill.$^{96}$

\section{Summary}

In the face of rapidly spreading disease and a large number of infected people, it is necessary to use effective procedures to prevent and control infections. Quick diagnostic methods are required to enable the selection of patients and contact persons. The lack of early identification of patients with COVID-19 can paralyze the functioning of medical facilities, disrupt public health systems, and cause substantial economic losses. More advanced research and data analysis of numerous groups of patients are needed to describe the transmission and treatment options accurately.

Even recently, we know more and more about COVID19 , still many questions remain unclear. There is a concern whether a cured patient is still susceptible to re-infection and whether the subsequent disease will have milder or more severe course. However, information indicating a confirmed virus source of origin and its pathogenesis may initiate medical studies and give direction to new drug synthesis and vaccine production.

Communication between the primary care system and national organs enables to plan the essential elements, which allow decreasing the spread of the infection. The most susceptible to infection patients (older people, pregnant women, immunocompromised patients, or patients with a chronic medical condition resulting in increased risk from coronavirus infection) should have the possibility to continue their treatment in the primary care system. On the other side, it is also essential for enabling vulnerable GPs and other medical specialists authorized to use telehealth item numbers to provide care for their patients using telehealth. Moreover, precise and 


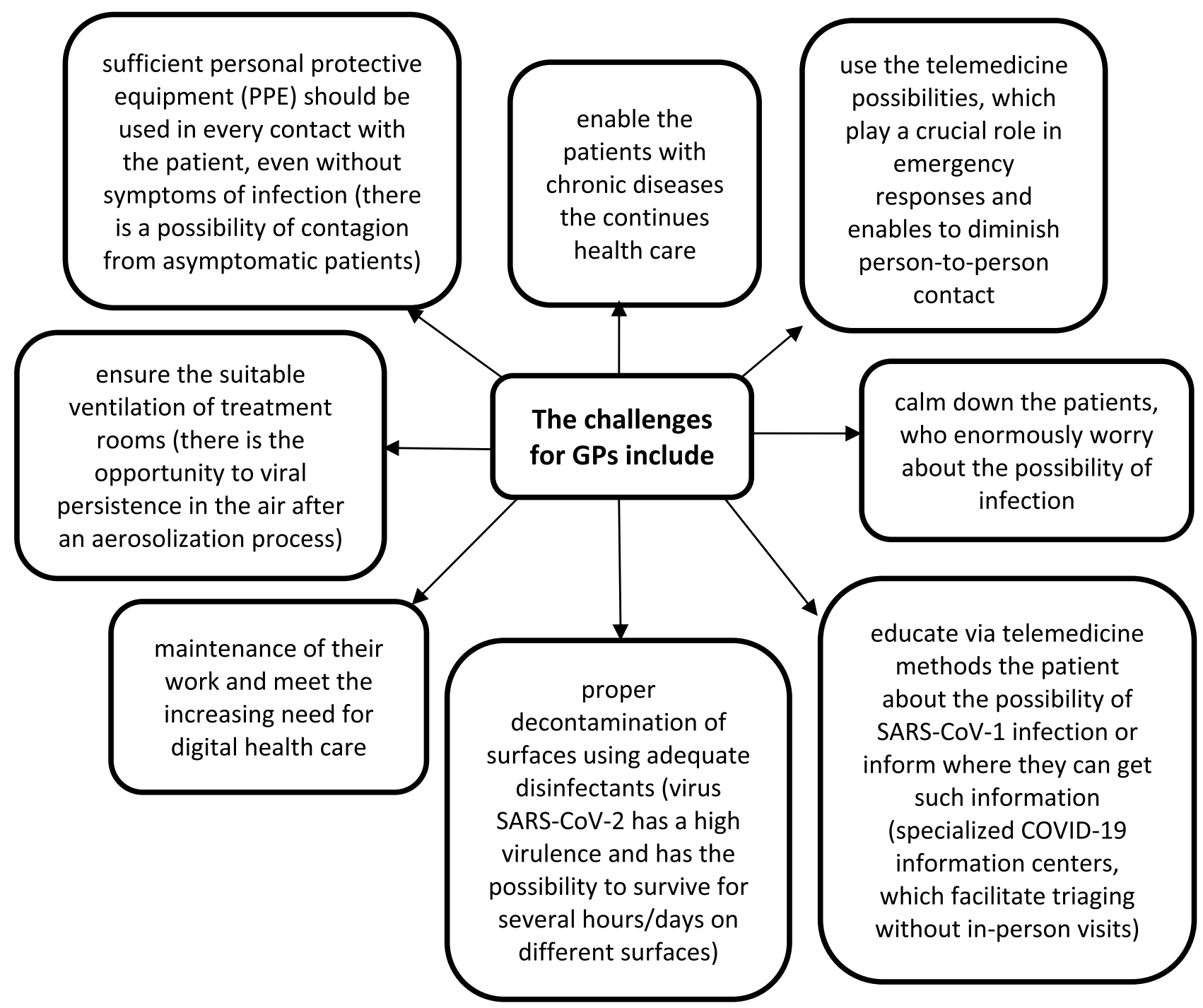

Figure I The challenges for GPs to reduce SARS-CoV-2 contagion rates (according to Modenese, Ing E, Li DKT, Hollander, Smith).

practical guidelines are urgent for the improvement of adequate measures to prevent SARS-CoV-2 infections among general practitioners.

\section{Ethical Approval}

None.

\section{Funding}

We declare no funding.

\section{Disclosure}

The authors report no conflicts of interest for this work.

\section{References}

1. Cui J, Li F, Shi Z. Origin and evolution of pathogenic coronaviruses. Nat Rev Microbiol. 2019;17:181-192. doi:10.1038/s41579-018-0118-9
2. Zhou P, Yang XL, Wang XG, et al. A pneumonia outbreak associated with a new coronavirus of probable bat origin. Nature. 2020;579:270-273. doi:10.1038/s41586-020-2012-7

3. Ji W, Wang W, Zhao X, Zai J, Li X. Homologous recombination within the spike glycoprotein of the newly identified coronavirus may boost cross-species transmission from snake to human. $J$ Med Virol. 2020;92:433-440. doi:10.1002/jmv.25682

4. Perera KD, Galasiti Kankanamalage AC, Rathnayake AD, et al. Protease inhibitors broadly effective against feline, ferret and mink coronaviruses. Antiviral Res. 2018;160:79-86. doi:10.1016/j. antiviral.2018.10.015

5. Guan WJ, Ni ZY, Hu Y, et al. China medical treatment expert group for Covid-19. Clinical Characteristics of Coronavirus Disease 2019 in China. N Engl J Med. 2020;382:1708-1720. doi:10.1056/NEJMoa2002032

6. Zimmermann P, Curtis N. Coronavirus infections in children including COVID-19: an overview of the epidemiology, clinical features, diagnosis, treatment and prevention options in children. Pediatr Infect Dis J. 2020;39(5):355-368. doi:10.1097/INF.0000000000002660

7. Zhao XY, Xu XX, Yin HS, et al. Clinical characteristics of patients with 2019 coronavirus disease in a non-Wuhan area of Hubei Province, China: a retrospective study. BMC Infect Dis. 2020;20:311. doi:10.1186/s12879-020-05010-w 
8. Chakraborty C, Sharma AR, Sharma G, Bhattacharya M, Lee SS. SARS-CoV-2 causing pneumonia-associated respiratory disorder (COVID-19): diagnostic and proposed therapeutic options. Eur Rev Med Pharmacol Sci. 2020;24(7):4016-4026. doi:10.26355/ eurrev_202004_20871

9. Li X, Zeng W, Li X, et al. CT imaging changes of corona virus disease 2019(COVID-19): a multicenter study in Southwest China. J Transl Med. 2020;18(1):154. doi:10.1186/s12967-020-02324-w

10. To KK, Tsang OT, Leung WS, et al. Temporal profiles of viral load in posterior oropharyngeal saliva samples and serum antibody responses during infection by SARS-CoV-2: an observational cohort study. Lancet Infect Dis. 2020;S1473-3099(20). doi:10.1016/S14733099(20)30196-1

11. Yu F, Du L, Ojcius DM, Pan C, Jiang S. Measures for diagnosing and treating infections by a novel coronavirus responsible for a pneumonia outbreak originating in Wuhan, China. Microbes Infect. 2020;22:74-79. doi:10.1016/j.micinf.2020.01.003

12. Hindson J. COVID-19: faecal-oral transmission? Nat Rev Gastroenterol Hepatol. 2020;17:259. doi:10.1038/s41575-020-0295-7

13. Zhou F, Yu T, Du R, et al. Clinical course and risk factors for mortality of adult inpatients with COVID-19 in Wuhan, China: a retrospective cohort study. Lancet. 2020;395:1054-1062. doi:10.1016/S0140-6736(20)30566-3

14. Andersen CJ, Murphy KE, Fernandez ML. Impact of obesity and metabolic syndrome on immunity. Adv Nutr. 2016;7:66- 75. doi:10.3945/an.115.010207

15. Wang D, Hu B, Hu C, et al. Clinical characteristics of 138 hospitalized patients with 2019 novel coronavirus-infected pneumonia in Wuhan, China. JAMA. 2020. doi:10.1001/jama.2020.1585

16. Flisiak R, Horban A, Jaroszewicz J, et al. Rekomendacje postępowania z infekcjami koronawirusem Polskiego Towarzystwa Epidemiologów i Zakaźników. Termedia. 2020. https://www.terme dia.pl/zalecenia/Rekomendacje-postepowania-z-infekcjami-

koronawirusem-Polskiego-Towarzystwa-Epidemiologow -i-Zakaznikow,37396.html.

17. Yang X, Yu Y, Xu J, et al. Clinical course and outcomes of critically ill patients with SARS-CoV-2 pneumonia in Wuhan, China: a single-centered, retrospective, observational study. Lancet Respir Med. 2020;S2213-2600(20). doi:10.1016/S2213-2600(20)30079-5

18. Wu Z, McGoogan JM. Characteristics of and important lessons from the coronavirus disease 2019 (COVID-19) outbreak in China: summary of a report of 72314 cases from the Chinese Center for Disease Control and Prevention. JAMA. 2020;323(13):1239. doi:10.1001/ jama.2020.2648

19. ECDC. European-Centre-for-Disease-Prevention-and-Control. Daily risk assessment on COVID-19, 2 March 2020 Available from: https://www.ecdc.europa.eu/en/current-risk-assessment-novelcoronavirus-situation. Accessed December 10, 2020.

20. Zheng. SARS-CoV-2: an emerging coronavirus that causes a global threat. Int J Biol Sci. 2020;16:1678-1685. doi:10.7150/ijbs.45053

21. Wu X, Dong D, Ma D. Thin-section computed tomography manifestations during convalescence and long-term follow-up of patients with Severe Acute Respiratory Syndrome (SARS). Med Sci Monit. 2016;22:2793-2799. doi:10.12659/MSM.896985

22. Ajlan AM, Ahyad RA, Jamjoom LG, Alharthy A, Madani TA. Middle East respiratory syndrome coronavirus (MERS-CoV) infection: chest CT findings. AJR Am J Roentgenol. 2014;203:782-787. doi:10.2214/AJR.14.13021

23. Peeri NC, Shrestha N, Rahman MS, et al. The SARS, MERS and novel coronavirus (COVID-19) epidemics, the newest and biggest global health threats: what lessons have we learned? Int J Epidemiol. 2020;pii:dyaa033. doi:10.1093/ije/dyaa033

24. Lu R, Zhao X, Li J, et al. Genomic characterisation and epidemiology of 2019 novel coronavirus: implications for virus origins and receptor binding. Lancet. 2020;395:565-574. doi:10.1016/S0140-6736(20)30251-8
25. Zhu N, Zhang D, Wang W, et al. China novel coronavirus investigating and research team. a novel coronavirus from patients with pneumonia in China, 2019. $N$ Engl J Med. 2020;382:727-733. doi:10.1056/NEJMoa2001017

26. Ye ZW, Yuan S, Yuen KS, Fung SY, Chan CP, Jin DY. Zoonotic origins of human coronaviruses. Int J Biol Sci. 2020;16:1686-1697. doi: $10.7150 /$ ijbs. 45472

27. World Health Organization. Coronavirus disease (COVID-2019) situation reports. Situation report e 33. Available from: https://www. who.int/emergencies/diseases/novel-coronavirus-2019/situationreports/. Accessed December 10, 2020.

28. Burki T. Outbreak of coronavirus disease 2019. Lancet Infect Dis. 2020;S1473-3099.

29. Chan JF, Lau SK, To KK, Cheng VC, Woo PC, Yuen KY. Middle East respiratory syndrome coronavirus: another zoonotic betacoronavirus causing SARS-like disease. Clin Microbiol Rev. 2015;28:465-522.

30. Cheng VCC, Lau SKP, Woo PCY, Yuen KY. Severe acute respiratory syndrome coronavirus as an agent of emerging and reemerging infection. Clin Microbiol Rev. 2007;20:660-694.

31. Gu J, Han B, Wang J. COVID-19: gastrointestinal manifestations and potential fecal-oral transmission. Gastroenterology. 2020;158 (6):1518-1519. doi:10.1053/j.gastro.2020.02.054

32. Lee IK, Wang CC, Lin MC, Kung CT, Lan KC, Lee CT. Effective strategies to prevent coronavirus disease-2019 (COVID-19) outbreak in hospital. J Hosp Infect. 2020. doi:10.1016/j.jhin.2020.02.022

33. Zou L, Ruan F, Huang M, et al. SARS-CoV-2 viral load in upper respiratory specimens of infected patients. $N$ Engl J Med. 2020;382 (12):1177-1179. doi:10.1056/NEJMc2001737

34. Li Q, Guan X, Wu P, et al. Early transmission dynamics in Wuhan, China, of novel coronavirus-infected pneumonia. $N$ Engl $\mathrm{J} \mathrm{Med}$. 2020;382:1199-1207. doi:10.1056/NEJMoa2001316

35. Zhang J, Litvinova M, Wang W, et al. Evolving epidemiology and transmission dynamics of coronavirus disease 2019 outside Hubei province, China: a descriptive and modelling study. Lancet Infect Dis. 2020. doi:10.1016/S1473-3099(20)30230-9

36. Linton NM, Kobayashi T, Yang Y, et al. Incubation period and other epidemiological characteristics of 2019 novel coronavirus infections with right truncation: a statistical analysis of publicly available case data. J Clin Med. 2020;9(2):E538. doi:10.3390/jcm9020538

37. Zhang ZJ, Yu XJ, Fu T, et al. Novel coronavirus infection in newborn babies aged 28days. Eur Respir J. 2020;55(6):2000697. doi:10.1183/ 13993003.00697-2020

38. Liu W, Wang J, Li W, Zhou Z, Liu S, Rong Z. Clinical characteristics of 19 neonates born to mothers with COVID-19. Front Med. 2020. doi:10.1007/s11684-020-0772-y

39. Epidemiology Working Group for NCIP Epidemic Response CCfDCaP. The epidemiological characteristics of an outbreak of 2019 novel coronavirus diseases (COVID-19) in China. Chinese J Epidemiol. 2020;41:145-151.

40. World Health Organization. World Report on Aging and Health. Luxembourg: WHO; 2015.

41. Wei M, Yuan J, Liu Y, Fu T, Yu X, ZJ Z. Novel coronavirus infection in hospitalized infants under 1 year of age in China. JAMA. 2020;323 (13):1313. doi:10.1001/jama.2020.2131

42. Cai J, Xu J, Lin D, et al. A case series of children with 2019 novel coronavirus infection: clinical and epidemiological features. Clin Infect Dis. 2020;pii:ciaa198. doi:10.1093/cid/ciaa198

43. Xia W, Shao J, Guo Y, Peng X, Li Z, Hu D. Clinical and CT features in pediatric patients with COVID-19 infection: different points from adults. Pediatr Pulmonol. 2020;55(5):1169-1174. doi:10.1002/ ppul.24718

44. Martineau AR, Jolliffe DA, Hooper RL, et al. Vitamin D supplementation to prevent acute respiratory tract infections: systematic review and meta-analysis of individual participant data. BMJ. 2017;356:i6583. doi:10.1136/bmj.i6583 
45. To KK, Tsang OT, Chik-Yan Yip C, et al. Consistent detection of 2019 novel coronavirus in saliva [published on February 12, 2020]. Clin Infect Dis. 2020;pii:ciaa149. doi:10.1093/cid/ciaa149

46. Mao R, Liang J, Wu KC, Chen MH. Responding to COVID-19: perspectives from the Chinese Society of Gastroenterology. Gastroenterology. 2020.

47. Luo S, Zhang X, Xu H. Don't overlook digestive symptoms in patients with 2019 novel coronavirus disease (COVID-19. Clin Gastroenterol Hepatol. 2020;18(7):1636-1637. doi:10.1016/j. cgh.2020.03.043

48. Chai X, Longfei H, Zhang Y, et al. Specific ACE2 expression in cholangiocytes may cause liver damage after 2019-nCoV infection. biorxiv. 2020:931766. DOI:10.1101/2020.02.03.931766

49. Leung WK, To KF, Chan PK, et al. Enteric involvement of severe acute respiratory syndrome associated coronavirus infection. Gastroenterology. 2003;25(4):1011-1017. doi:10.1016/j. gastro.2003.08.001

50. European Rhinologic Society. Information for rhinologists on COVID-19. Available from: https://www.europeanrhinologicsociety. org/?page_id=2143. Accessed December 10, 2020.

51. Lechien JR, Chiesa-Estomba CM, De Siati DR, et al. Olfactory and gustatory dysfunctions as a clinical presentation of mild-to-moderate forms of the coronavirus disease (COVID-19): a multicenter European study. Eur Arch Otorhinolaryngol. 2020;277 (8):2251-2261. doi:10.1007/s00405-020-05965-1

52. Russell FM, Reyburn R, Chan J, et al. Impact of the change in WHO's severe pneumonia case definition on hospitalized pneumonia epidemiology: case studies from six countries. Bull World Health Organ. 2019;97:386-393.

53. Lin X, Gong Z, Xiao Z, Xiong J, Fan B, Liu J. Novel coronavirus pneumonia outbreak in 2019: computed tomographic findings in two cases. Korean J Radiol. 2020;21:365-368. doi:10.3348/kjr.2020.0078

54. Fang Y, Zhang H, Xie J, et al. Sensitivity of Chest CT for COVID-19: comparison to RT-PCR. Radiology. 2020;19:200432.

55. Wu J, Liu J, Li S, et al. Detection and analysis of nucleic acid in various biological samples of COVID-19 patients. Travel Med Infect Dis. 2020;37:101673. doi:10.1016/j.tmaid.2020.101673

56. Tang B, Wang X, Li Q, et al. Estimation of the transmission risk of the 2019-nCoV and its implication for public health interventions. J Clin Med. 2020;9:1-13. doi:10.3390/jcm9020462

57. Corman VM, Landt O, Kaiser M, et al. Detection of 2019 novel coronavirus (2019-nCoV) by real-time RT-PCR. Euro Surveill. 2020;25:1-8. doi:10.2807/1560-7917.ES.2020.25.3.2000045

58. CDC. Interim Guidelines for Collecting, Handling, and Testing Clinical Specimens from Persons for Coronavirus Disease 2019 (COVID-19) Available from: https://www.cdc.gov/coronavirus/2019-ncov/lab/guide lines-clinical-specimens.html. Accessed December 10, 2020.

59. NEJM. SARS-CoV-2 Viral Load in Upper Respiratory Specimens of Infected Patients Available from: https://www.nejm.org/doi/full/10. 1056/NEJMc2001737. Accessed December 10, 2020.

60. Lin C, Xiang J, Yan M, Li H, Huang S, Shen C. Comparison of throat swabs and sputum specimens for viral nucleic acid detection in 52 cases of novel coronavirus (SARS-Cov-2)-infected pneumonia (COVID-19). Clin Chem Lab Med. 2020;58(7):1089-1094. doi:10.1515/cclm-2020-0187

61. Mash MB. Primary care management of the coronavirus (COVID-19). S Afr Fam Pract. 2004;2020(62):e1-e4.

62. Jin YH, Cai L, Cheng ZS, et al. Evidence-based medicine chapter of china international exchange and promotive association for medical and health Care (CPAM). A rapid advice guideline for the diagnosis and treatment of 2019 novel coronavirus (2019-nCoV) infected pneumonia (standard version). Mil Med Res. 2020;7(1):4. doi:10.1186/ s40779-020-0233-6

63. Yan G, Lee CK, Lam LTM, et al. Covert COVID-19 and false-positive dengue serology in Singapore. Lancet Infect Dis. 2020;S1473-3099(20). doi:10.1016/S1473-3099(20)30158-4
64. Vincent JL, Moreno R, Takala J, et al. (Sepsis-related Organ Failure Assessment) score to describe organ dysfunction/failure. On behalf of the Working Group on Sepsis-Related Problems of the European Society. Intensive Care Med. 1996;22:707-710. doi:10.1007/ BF01709751

65. Kwon YS, Baek MS. Development and validation of a quick sepsis-related organ failure assessment-based machine-learning model for mortality prediction in patients with suspected infection in the emergency department. $J$ Clin Med. 2020;9(3):E875. doi: $10.3390 /$ jcm 9030875

66. $\mathrm{Hu} \mathrm{H}$, Yao N, Qiu Y. Comparing rapid scoring systems in mortality prediction of critical ill patients with novel coronavirus disease. Acad Emerg Med. 2020;27(6):461-468. doi:10.1111/acem.13992

67. Liu JW, Lu SN, Chen SS, et al. Epidemiologic study and containment of a nosocomial outbreak of severe acute respiratory syndrome in a medical center in Kaohsiung, Taiwan. Infect Control Hosp Epidemiol. 2006;27:466-472. doi:10.1086/504501

68. Yousefifard M, Zali A, Mohamed AK, et al. Antiviral therapy in management of COVID-19: a systematic review on current evidence. Arch Acad Emerg Med. 2020;8:e45.

69. Damle B, Vourvahis M, Wang E, Leaney J, Corrigan B. Clinical pharmacology perspectives on the antiviral activity of azithromycin and use in COVID-19. Clin Pharmacol Ther. 2020;108(2):201-211. doi:10.1002/cpt.1857

70. Wu R, Wang L, Kuo HD, et al. An update on current therapeutic drugs treating COVID-19 [published online ahead of print, 2020 May 11]. Curr Pharmacol Rep. 2020:1-15. doi:10.1007/s40495-02000216-7.

71. Wang, Wang Y, Zhang D, et al. Remdesivir in adults with severe COVID-19: a randomised, double-blind, placebo-controlled, multicentre trial. The Lancet. 2020;395(10236):1569-1578.

72. Grein et al. 2020. Compassionate Use of Remdesivir for Patients with Severe Covid-19. Available from: https://www.nejm.org/doi/full/10. 1056/NEJMoa2007016. Accessed December 10, 2020.

73. Liu J, Cao R, Xu M, et al. Hydroxychloroquine, a less toxic derivative of chloroquine, is effective in inhibiting SARS-CoV-2 infection in vitro. Cell Discov. 2020;6(16). doi:10.1038/s41421-020-0156-0

74. Wang M, Cao R, Zhang L, et al. Remdesivir and chloroquine effectively inhibit the recently emerged novel coronavirus (2019-nCoV) in vitro. Cell Res. 2020;30:269-271. doi:10.1038/s41422-020-0282-0

75. Gautret P, Lagier JC, Parola P, et al. Hydroxychloroquine and azithromycin as a treatment of COVID-19: results of an open-label non-randomized clinical trial. Int $J$ Antimicrob Agents. 2020;56 (1):105949. doi:10.1016/j.ijantimicag.2020.105949

76. Yao X, Ye F, Zhang M, et al. In vitro antiviral activity and projection of optimized dosing design of hydroxychloroquine for the treatment of Severe Acute Respiratory Syndrome Coronavirus 2 (SARS-CoV2). Clin Infect Dis. 2020;pii:ciaa237. doi:10.1093/cid/ciaa237

77. Cao, Cao B, Wang Y, et al. A trial of lopinavir-ritonavir in adults hospitalized with severe Covid-19. NEJM. 2020;382(19):1787-1799.

78. Ye, et al. Clinical efficacy of lopinavir/ritonavir in the treatment of Coronavirus disease 2019. Eur Rev Med Pharmacol Sci. 2020;24 (6):3390-3396. doi:10.26355/eurrev_202003_20706

79. Xiaoling et al. 2020. Effective Treatment of Severe COVID-19 Patients with Tocilizumab. pdf download

80. Gritti G, et al. Use of siltuximab in patients with COVID-19 pneumonia requiring ventilatory support. medRxiv. 2020.

81. Caly L, Druce JD, et al. The FDA-approved drug ivermectin inhibits the replication of SARS-CoV-2 in vitro. Antiviral Research. 2020;178:104787. doi:10.1016/j.antiviral.2020.104787

82. Shen C, Wang Z, Zhao F, et al. Treatment of 5 critically ill patients with COVID-19 with convalescent plasma. JAMA. 2020;323 (16):1582. doi:10.1001/jama.2020.4783

83. Duan, et al. The feasibility of convalescent plasma therapy in severe COVID-19 patients: a pilot study. MedRxiv. doi:10.1101/ 2020.03.16.20036145 
84. Villar, Villar J, Ferrando C, et al. Dexamethasone treatment for the acute respiratory distress syndrome: a multicentre, randomised controlled trial. Lancet Respir Med. 2020;8(3):267-276. doi:10.1016/ S2213-2600(19)30417-5

85. Tang N, Bai H, Chen X, Gong J, Li D, Sun Z. Anticoagulant treatment is associated with decreased mortality in severe coronavirus disease 2019 patients with coagulopathy. J Thromb Haemost. 2020. doi: $10.1111 /$ jth. 14817

86. Zhong M, Sun A, Xiao T, et al. A randomized, single-blind, group sequential, active-controlled study to evaluate the clinical efficacy and safety of $\alpha$-Lipoic acid for critically ill patients with coronavirus disease 2019 (COVID-19) (preprint). Pharmacol Ther. 2020. doi:10.1101/2020.04.15.20066266

87. McCarty MF, DiNicolantonio JJ. Nutraceuticals have potential for boosting the type 1 interferon response to RNA viruses including influenza and coronavirus. Prog Cardiovasc Dis. 2020;63 (3):383-385. doi:10.1016/j.pcad.2020.02.007

88. Schultz MJ, Dunser MW, Dondorp AM, et al. Global Intensive Care Working Group of the European Society of Intensive Care Medicine. Intensive Care Med. 2017;43:612-624. doi:10.1007/s00134-0174750-z

89. Shah S, Das S, Jain A, Misra DP, Negi VS. A systematic review of the prophylactic role of chloroquine and hydroxychloroquine in coronavirus disease-19 (COVID-19). Int J Rheum Dis. 2020;23 (5):613-619. doi:10.1111/1756-185X.13842
90. Horby P, WS L, Emberson J, et al. Effect of dexamethasone in hospitalized patients with COVID-19: preliminary report RECOVERY Collaborative Group medRxiv 2020. doi: 10.1101/ 2020.06.22.20137273

91. Tobin MJ, Laghi F, Jubran A. Caution about early intubation and mechanical ventilation in COVID-19. Ann Intensive Care. 2020;10 (78). doi:10.1186/s13613-020-00692-6

92. Dondorp AM, Hayat M, Aryal D, Beane A, Schultz MJ. Respiratory support in COVID-19 patients, with a focus on resource-limited settings. Am J Trop Med Hyg. 2020;102(6):1191-1197. doi:10.4269/ ajtmh.20-0283

93. Masotti P, Green ME, Birtwhistle R, et al. pH1N1 - a comparative analysis of public health responses in Ontario to the influenza outbreak, public health and primary care: lessons learned and policy suggestions. BMC Public Health. 2013;13:687. doi:10.1186/14712458-13-687

94. Modenese A, Gobba F. Increased risk of COVID-19-related deaths among general practitioners in Italy. Healthcare (Basel). 2020;2:155. doi:10.3390/healthcare8020155

95. Ing EB, Xu QA, Salimi A, Torun N. Physician deaths from corona virus (COVID-19) disease. Occup Med (Lond) Actions. 2020;

96. Li DKT, Zhu S. Contributions and challenges of general practitioners in China fighting against the novel coronavirus crisis. Fam Med Com Health. 2020;8(2):e000361. doi:10.1136/fmch-2020-000361
Clinical Interventions in Aging

\section{Publish your work in this journal}

Clinical Interventions in Aging is an international, peer-reviewed journal focusing on evidence-based reports on the value or lack thereof of treatments intended to prevent or delay the onset of maladaptive correlates of aging in human beings. This journal is indexed on PubMed Central, MedLine, CAS, Scopus and the Elsevier

\section{Dovepress}

Bibliographic databases. The manuscript management system is completely online and includes a very quick and fair peer-review system, which is all easy to use. Visit http://www.dovepress.com testimonials.php to read real quotes from published authors. 